Науковий вісник Нлту України
Scientific Bulletin of UNFU
https://nv.nltu.edu.ua
$\begin{gathered}\text { https://doi.org/10.36930/40290928 } \\ \text { Article received 13.11.2019 p. } \\ \text { Article accepted 26.12.2019 p. } \\ \text { UDK 681.5.017 }\end{gathered}$ $\begin{array}{r}\text { ISSN 1994-7836 (print) } \\ \text { ISSN 2519-2477 (online) } \\ \begin{array}{l}\text { H. B. Krykh } \\ \text { gannakrih@gmail.com }\end{array}\end{array}$

Г. Б. Крих, Г. Ф. Матіко, Б. А. Кріль

Національний університет "Львівська політехніка", м. Львів, Украйна

\title{
МОДЕЛЮВАННЯ СИСТЕМИ КЕРУВАННЯ 3 РЕГУЛЯТОРОМ НА ПІДСТАВІ ВНУТРІШНЬОЇ МОДЕЛІ
}

\begin{abstract}
Засобами імітаційного моделювання проаналізовано функціонування замкнутих систем керування в умовах зміни властивостей інерційного об'єкта керування. Порівняли роботу таких систем: одноконтурної з ПІД регулятором, багатоконтурних з ПІ-ПД керуванням та систем із зовнішнім регулятором на підставі внутрішньої моделі. Серед систем керування із внутрішньою моделлю одна побудована на підставі моделі об'єкта керування. Ми запропонували іншу система, в якій структура зовнішнього регулятора реалізована на базі внутрішньої моделі замкнутого внутрішнього контуру з ПД регулятором. Для спрощення процедури налаштування зовнішнього регулятора вибрано наближену модель об'єкта керування у вигляді послідовно з'єднаних аперіодичної ланки першого порядку та ланки запізнення. Знайдено наближену внутрішню модель зустрічного паралельного з'єднання об'єкта керування та ПД регулятора та отримано наближену обернену модель. Встановлено, що в умовах зміни властивостей об'єкта керування запропонована система зберігає достатній запас стійкості і порівняно з іншими досліджуваними системами має переваги. Так, зі збільшенням коефіцієнта передачі об'єкта керування у 2 рази та збільшенням інерційності на $30 \%$ перехідні процеси каналом заданого значення мають найменший час регулювання. Окрім цього, каналом збурення така система забезпечує найменше динамічне відхилення для всіх варіантів дослідження.

Ключові слова: об'єкт керування; структурна схема; структура регулятора; перехідні процеси; показники якості.
\end{abstract}

Вступ. Сучасні технологічні процеси оснащені багатьма системами автоматичного керування. Складність керування зумовлена, зокрема, значною інерційністю технологічних об'єктів та роботою в різних режимах, пов'язаних, зокрема, зі зміною навантаження. У таких умовах важливо забезпечити належну якість систем автоматичного керування, від якої залежать ефективність та безпека технологічних процесів та виробництва загалом. Одноконтурні системи керування з типовими класичними регуляторами не завжди можуть задовольнити вимоги до процесу керування, а їх переналаштування під час функціонування об'єкта керування (ОК) потребує фахового втручання. Тому актуальною задачею є побудова робастних систем керування, які підтримували б регульовану величину в допустимих межах при зміні властивостей ОК.

Аналіз останніх досліджень і публікацій. Для вирішення різноманітних задач керування найпоширенішими є замкнуті системи з ПІД алгоритмом керуванням. Вони ефективно працюють зі стаціонарними об'єктами і мають достатній запас стійкості за незначних змін властивостей ОК (Astrom \& Hagglund, 2005; Denysenko, 2009). Для інерційних об'єктів розроблені системи 3 предиктором Сміта та його модифікації, сис- теми із внутрішньою моделлю, в яких регульована величина прогнозується на підставі моделі об'єкта керування (Kovrygo et al., 2017; Movchan \& Stepanets, 2011; Zhukov \& Vazhynskyi, 2017). Теоретично такі системи дають змогу зменшити перерегулювання, час регулювання, коливальність перехідних процесів (Karakawa et al., 2002). Особливу увагу під час створення таких систем приділяють питанням вибору внутрішньої моделі та налаштування регуляторів для забезпечення робастності та досконалості керування (Wang et al., 2006; Remizova \& Fokin, 2016; Vilanova et al., 2018). У роботі (Kovrygo \& Bahan, 2015) на підставі аналізу проблем керування інерційними контурами доведено доцільність застосування структур регуляторів із внутрішньою моделлю на базі $\mathrm{H}_{\infty}$-норми замкненої системи. Регулятор, налаштований на найгірший режим об'єкта, гарантує стійкість і приводить до показників якості функціонування, не гірших від заданих в інших режимах роботи.

Окрім систем із внутрішньою моделлю з одним ступенем свободи досліджені також регулятори із двома ступенями свободи, які дають змогу отримати задані показники якості для каналів зовнішнього збурення i завдання. У роботі (Kovrygo et al., 2014) запропоновано

\section{Інформація про авторів}

Крих Ганна Бориславівна, канд. техн. наук, доцент, кафедра автоматизації та комп'ютерно-інтегрованих технологій. Email: gannakrih@gmail.com; https://orcid.org/0000-0002-6539-400X

Матіко Галина Федорівна, канд. техн. наук, доцент, кафедра теплоенергетики, теплових та атомних електричних станцій. Email: halynamatiko@gmail.com; https://orcid.org/0000-0001-5482-2307

Кріль Богдан Андрійович, канд. техн. наук, ст. наук. співробітник, доцент, кафедра автоматизації та комп'ютерно-інтегрованих технологій. Email: kril@robitnia.com

Цитування за ДстУ: Крих Г. Б., Матіко Г. Ф., Кріль Б. А. Моделювання системи керування з регулятором на підставі внутрішньої моделі. Науковий вісник НЛТУ України. 2019, т. 29, № 9. С. 161-168.

Citation APA: Krykh, H. B., Matiko, H. F., \& Kril, B. A. (2019). Simulating the system based on internal model control. Scientific Bulletin of UNFU, 29(9), 161-168. https://doi.org/10.36930/40290928 
методику синтезу робастного регулятора, згідно з якою канали керування налаштовують окремо без впливу одного на інший.

У роботі (Movchan \& Stepanets, 2011) розглянуто складніші каскадні системи керування, в яких допоміжний та основний контури реалізовані на підставі внутрішньої моделі об'єкта. Об'єднання структури регуляторів із внутрішньою моделлю має переваги порівняно 3 ПІД регуляторами. Налаштування регуляторів за допомогою адаптивного комплексу забезпечує необхідні показники якості i дає змогу спроектувати стійку до дрейфу параметрів систему керування теплоенергетичними контурами (Stepanets, 2012).

Для інерційних об'єктів керування зі змінними властивостями в роботах (Kovrygo et al., 2013; Kovrygo et al., 2016) запропоновано нову структуру ПІ-регулятора 3 динамічним коректором, застосування якого задовольняє жорсткі вимоги до швидкості роботи та мінімізації перегулювання при зміні режимів роботи теплоенергетичних об'єктів. Використання корегувального каналу разом 3 форсуванням штатного ПІ-регулятора поліпшує прямі показники якості, такі як динамічний закид, час регулювання і ступінь згасання коливань у маневрених режимах.

Модифікована форма ПІД контролера зі структурою ПІ-ПД відповідає ПІ контролеру з функцією передачі ОК, зміненою за допомогою ПД зворотного зв'язку, що покращує показники керування, особливо для нестабільних процесів (Onat, 2018). У статтях подано різні методи налаштування параметрів робастних ПІ-ПД контролерів для керування нестабільними процесами із затримкою в часі і без запізнення (Kaya, 2003; Hassaan, 2014; Hazem et al., 2016). У роботі (Dogruer \& Tan, 2019), зокрема, наведено метод визначення оптимальних параметрів ПІ-ПД контролера за допомогою еталонної моделі системи, побудованій за допомогою дробової функції передачі. Для мінімізації різниці вихідних сигналів системи з ПІ-ПД керуванням і еталонної моделі системи застосований ITSE критерій оптимізації.

Різноманітність задач керування та жорсткі вимоги до функціонування технологічних об'єктів в різних галузях зумовлює потреба подальших досліджень систем керування. Це особливо стосується інерційних об'єктів, властивості яких змінюються під час технологічних операцій. Для встановлення найкращої структури системи керування технологічним об'єктом зі змінними властивостями потрібно провести порівняльний аналіз показників якості процесів регулювання в системах керування різної структури.

Об'єктом дослідження є системи автоматичного керування технологічними об'єктами зі змінними властивостями.

Предметом дослідження є методи і засоби розроблення системи, що реалізує ПІ-ПД принцип керування та керування з внутрішньою моделлю об'єкта керування.

Мета дослідження - підвищення показників якості замкнутої системи автоматичного керування, яка мала б достатній запас стійкості і задовільні показники якості у разі зміни властивостей об'єкта керування. Досягти цієї мети можна, розв'язавши такі задачі дослідження:

- вдосконалити структурну схему системи керування із внутрішньою моделлю;

• вибрати спрощений метод знаходження моделі об'єкта керування з самовирівнюванням;
- спростити вибір параметрів регуляторів запропонованої системи;

- проаналізувати роботу одноконтурної системи з ПІД керуванням та багатоконтурних систем 3 ПІ-ПД керуванням, систем із внутрішньою моделлю в умовах зміни параметрів моделі ОК;

- дослідити показники якості запропонованої системи керування за допомогою імітаційного моделювання.

Методи дослідження. Для досягнення поставленої мети у роботі застосовано методи теорії автоматичного керування, апарат функцій передачі, імітаційне комп'ютерне моделювання. Для порівняльного аналізу роботи систем керування 3 різними структурними схемами та регуляторами застосовано методи імітаційного моделювання в середовищі Matlab/Simulink.

Результати дослідження. Методи підвищення якості систем керування поділяють на параметричні та структурні. У параметричних методах для певної структури системи керування знаходять такі параметри налаштування регулювальних пристроїв, які задовольняють задані характеристики. Такими характеристиками $є$ зазвичай прямі показники якості (час регулювання, максимальне динамічне відхилення), ступінь коливальності, інтегральні показники, запас стійкості тощо. Так, для одноконтурної системи керування (рис. 1) з ПІД регулятором

$$
W_{\text {ПІд }}(s)=k_{p}+\frac{k_{i}}{s}+k_{d} s
$$

коефіцієнти $k_{p}, k_{i}, k_{d} \epsilon$ параметрами налаштування відповідно пропорційної, інтегральної та диференціальної складових регулятора.

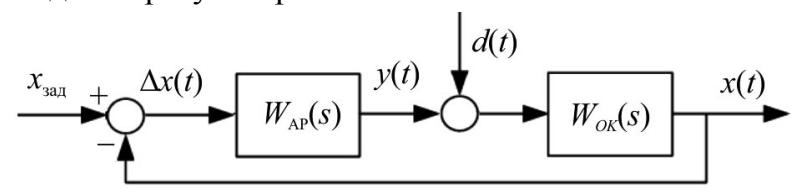

Рис. 1. Спрощена схема одноконтурної системи керування

У структурних методах для покращання показників якості змінюють структурну схему системи керування або введенням додаткових елементів, або введенням додаткових зворотних зв'язків. Так, в схемі системи керування, показаній на рис. 2, автоматичний регулятор реалізований за допомогою оберненої моделі $W_{O M}(s)$ об'єкта керування, фільтра $W_{\Phi}(s)$ у прямому зв'язку та спрощеної моделі ОК $W_{M}(s)$ у додатному зворотному зв'язку. Така схема реалізує керування, яке в іноземній літературі називають IMC (англ. Internal Model Control) (Astrom \& Hagglund, 2006).

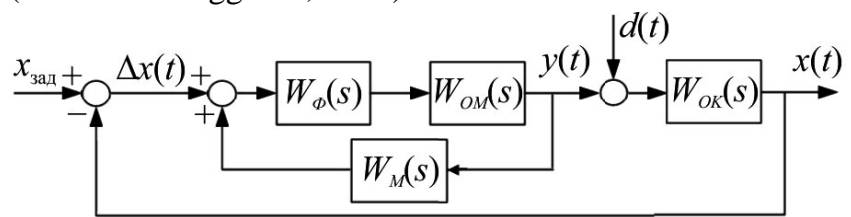

Рис. 2. Структурна схема системи керування із внутрішньою моделлю об'єкта керування

У системі керування з ПІ-ПД керуванням (рис. 3), окрім основного жорсткого зворотного зв'язку та зовнішнього ПІ регулятора, застосовано внутрішній гнучкий від'ємний зворотний зв'язок із ПД регулятором.

Основним предметом нашого дослідження є система керування (рис. 4) із внутрішнім гнучким від'ємним зворотним зв'язком з ПД регулятором та регулятором, 
реалізованим за допомогою спрощеної моделі зустрічного паралельного з'єднання об'єкта керування та ПД регулятора, оберненої до неї моделі $W_{O M}(s)$ і фільтра $W_{\Phi}(s)$.

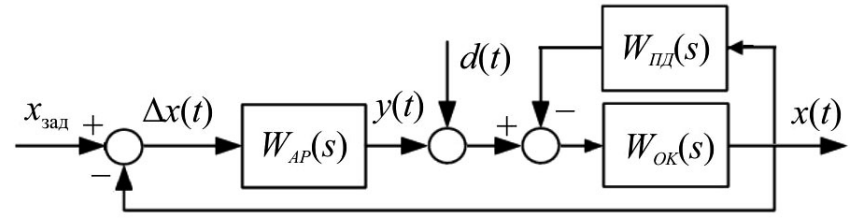

Рис. 3. Структурна схема системи керування з ПІ-ПД керуванням

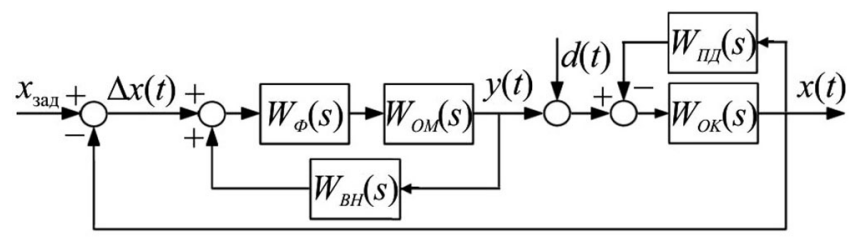

Рис. 4. Структурна схема системи керування із внутрішньою моделлю замкнутого контуру з ПД регулятором

У схемах, показаних на рис. 1-4, застосовано такі позначення: $W_{O K}(s), W_{A P}(s)$ - функції передачі об'єкта керування та автоматичного регулятора, $W_{\text {Пд }}(s)-$ функція передачі ПД регулятора, $W_{M}(s)$ - спрощена модель об'єкта керування, $W_{\Phi}(s)$ - функція передачі фільтра, $W_{B H}(s)$ - модель замкнутого контуру з ПД регулятором, $W_{O M}(s)$ - обернена модель; $y(t)$ - керуюча дія, $x_{\text {зад }}$ - задане значення регульованої величини $x(t), \square x(t)-$ відхилення регульованої величини від заданого значення, $d(t)$ - збурення.

Запишемо функцію передачі внутрішнього контуру системи, схему якої показано на рис. 4:

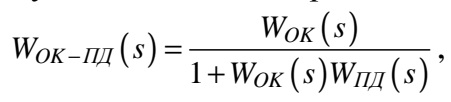

де $W_{O K}(s), W_{\text {Пд }}(s)$ - функції передачі об'єкта керування та ПД регулятора, відповідно. 3 урахуванням моделі зовнішнього регулятора (див. рис. 4)

$$
W_{A P}(s)=\frac{W_{\Phi}(s) W_{O M}(s)}{1-W_{\Phi}(s) W_{O M}(s) W_{B H}(s)},
$$

функція передачі досліджуваної системи за зміною за-

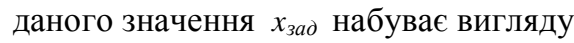

$$
W(s)=\frac{W_{\Phi}(s) W_{O M}(s) W_{O K-П Д}(s)}{1+W_{\Phi}(s) W_{O M}(s)\left(W_{O K-П Д}(s)-W_{B H}(s)\right)} .
$$

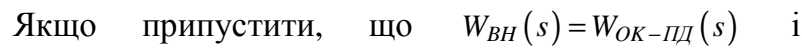
$W_{O M}(s)=W_{O K-П д}^{-1}(s)$,

$$
\text { то } \quad W(s)=W_{\Phi}(s) \text { і } x(s)=W_{\Phi}(s) x_{\text {зад }}(s) \text {. }
$$

Із формули (5) видно, що динамічні властивості системи визначатимуться моделлю фільтра.

Припустимо, що об'єкт керування описується адекватною моделлю

$$
W_{\text {OK }}(s)=\frac{k}{\left(T_{0} s+1\right)^{3}} .
$$

Тоді функція передачі внутрішнього контуру з ідеальним ПД регулятором $W_{\text {Пд }}(s)=k_{p 1}+k_{d 1} s$ згідно 3 формулою (2) матиме вигляд

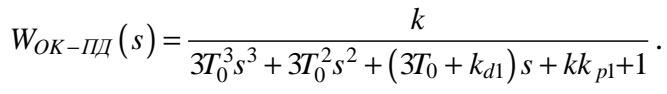

Якщо прийняти $W_{B H}(s)=W_{O K-\Pi Д}(s)$, то обернена модель $W_{O M}(s)=W_{B H}^{-1}(s)=W_{O K-п д}^{-1}(s)$ і їі реалізація ускладнена операціями диференціювання. Тому для побудови регулятора необхідно вводити фільтр. Загалом модель фільтра вибирають такою:

$$
W_{\Phi}(s)=\frac{1}{\left(T_{\Phi} s+1\right)^{n}} .
$$

$\mathrm{У}$ нашому випадку для побудови зовнішнього регулятора кількість аперіодичних ланок фільтра має бути не менше 3.

Спростимо обернену модель $W_{O M}(s)$ і для iї знаходження замість точної моделі об'єкта керування (6) застосуємо його наближену модель у вигляді послідовного з'єднання аперіодичної ланки першого порядку та ланки запізнення

$$
W_{M}(s)=\frac{k}{T s+1} \mathrm{e}^{-\tau s} .
$$

Функція передачі внутрішнього контуру з моделлю об'єкта керування (9) матиме вигляд

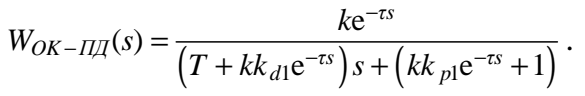

Представимо модель внутрішнього контуру (10) у такому наближеному вигляді:

$$
W_{B H}(s)=\frac{\mathrm{e}^{-\tau s}}{\left(T / k+k_{d}\right) s+k_{p 1}+1 / k},
$$

тоді наближену обернену модель знайдемо $з$ рівняння (11)

$$
W_{O M}(s)=\left(T / k+k_{d 1}\right) s+\left(k_{p 1}+1 / k\right) .
$$

Зауважимо, що в стані рівноваги $W_{B H}(0) W_{O M}(0)=1$. Оскільки отримана модель (12) є ідеальною диференціальною ланкою, то фільтр виберемо у вигляді аперіодичної ланки першого порядку

$$
W_{\Phi}(s)=\frac{1}{T_{\Phi} s+1} .
$$

Із врахуванням формул (11), (12), (13) автоматичний регулятор буде описуватись моделлю

$$
W_{A P}(s)=\frac{\left(T / k+k_{d 1}\right) s+\left(k_{p 1}+1 / k\right)}{T_{\Phi} s+1-\mathrm{e}^{-\tau s}} .
$$

Із рівняння (14) видно, що параметри налаштування автоматичного регулятора залежать від параметрів $k, T, \tau$ моделі (8) об'єкта керування, параметрів налаштування $k_{p 1}, k_{d 1}$ ПД регулятора та сталої часу $T_{\Phi}$ фільтра.

Якщо продовжити подальші спрощення, а саме, апроксимувати ланку запізнення $\mathrm{e}^{-\tau s}=1-\tau s$, то отримуємо ПІ регулятор

$$
W_{A P}(s)=k_{p 2}+\frac{k_{i 2}}{s}
$$

3 такими параметрами налаштування пропорційної та інтегральної складових:

$$
k_{p 2}=\frac{T / k+k_{d 1}}{T_{\Phi}+\tau}, k_{i 2}=\frac{k_{p 1}+1 / k}{T_{\Phi}+\tau} .
$$

Для дослідження виберемо об'єкт керування, модель якого отримана $з$ експериментальної кривої розгону ОК і має вигляд

$$
W_{O K}(s)=\frac{0,6222}{(3,5231 s+1)^{3}} \text {. }
$$


Параметри наближеної моделі об'єкта керування (9) знайдені з умови забезпечення мінімуму середньої абсолютної похибки

$$
\Delta_{O K}=\frac{1}{N} \sum_{i=1}^{N}\left|x\left(t_{i}\right)-x^{e}\left(t_{i}\right)\right|
$$

апроксимації експериментальної кривої розгону і дорівнюють $k=0,6222, \frac{{ }^{\circ} \mathrm{C}}{\% \text { ходу РО }}, T=6,4761, \tau=4,5433$. Розмірність всіх сталих часу, часу запізнення та інших часових показників тут і надалі подано у хвилинах.

Для знаходження параметрів моделі (9) ми проаналізували спрощений графоаналітичний метод, який базується на методі Ормана. Він дає змогу легко визначити параметри моделі (9) за експериментальною кривою розгону. Для знаходження $\square$ і $T$ з графіка нормованої кривої розгону (рис. 5) визначено моменти часу $t_{03}=$ 7,17616 i $t_{07}=12,73800$, для яких $h\left(t_{03}\right)=0,33$ i $h\left(t_{07}\right)=$ 0,7 , за якими розраховані час запізнення $\square$ і стала часу $T$ можна визначити за такими формулами:

$$
\tau=0,5 \cdot\left(3 t_{03}-t_{07}\right)=4,3952, T=1,25 \cdot\left(t_{07}-t_{03}\right)=6,9523 \text {. (19) }
$$

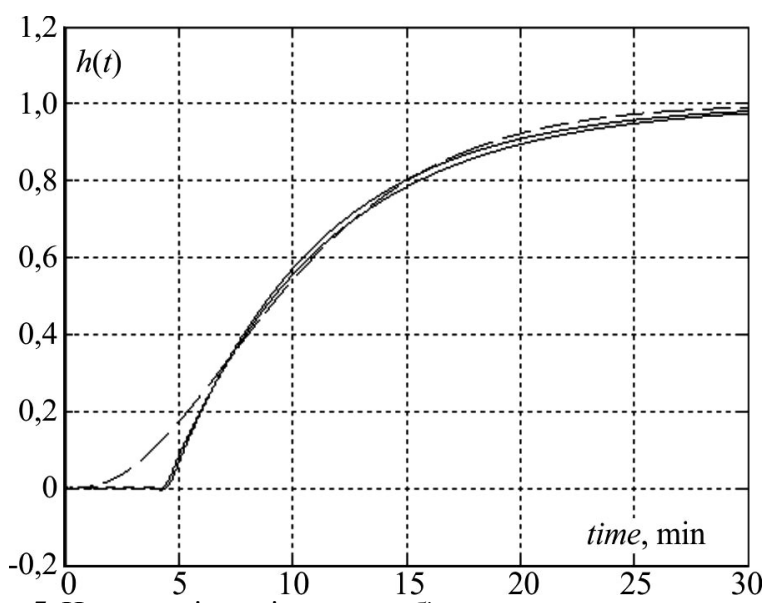

Рис. 5. Нормовані криві розгону об'єкта керування: апроксимація моделлю (17) (пунктирна лінія); апроксимація моделлю (9) точним та графоаналітичним методами (суцільні лінії)

Із рис. 5 видно, що графоаналітичний метод дає змогу визначити параметри моделі (9), які практично забезпечують мінімум середньої абсолютної похибки $\Delta_{O K}$. Тому надалі застосуємо таку наближену модель:

$$
W_{M}(s)=\frac{0,6222}{6,9523 s+1} \mathrm{e}^{-4,3952 s} .
$$

Із врахуванням моделі ПД регулятора

$$
W_{\text {Пд }}(s)=0,5+5 s
$$

внутрішня модель у схемі на рис. 4 згідно 3 формулою (11) набуде вигляду

$$
W_{B H}(s)=\frac{\mathrm{e}^{-4,3952 s}}{16,1737 s+2,1072} .
$$

Із врахуванням оберненої моделі (12) для схеми, наведеної на рис. 4, матимемо

$$
W_{O M}(s)=16,1737 s+2,1072,
$$

внаслідок чого реалізуємо регулятор, вибравши для цього послідовно з'єднаний фільтр (13) із сталою часу $T_{\phi}=\tau=4,3952$.

Проаналізуємо роботу п'яти систем керування в умовах зміни параметрів моделі ОК:

№ 1. Одноконтурної системи з ПІД регулятором, параметри якого розраховані за моделлю об'єкта керування (17) на ступінь коливальності $m=0,8$

$$
W_{\text {ПІд }}(s)=1,6476+\frac{0,2443}{s}+2,5 s \text {. }
$$

№ 2. Багатоконтурної системи із зовнішнім ПІ регулятором

$$
W_{\text {III }}(s)=0,8562+\frac{0,1566}{s},
$$

параметри якого розраховані за моделлю об'єкта керування (17) при $m=0,8$ та внутрішнім ПД регулятором (21).

№ 3. Одноконтурної системи з регулятором, побудованим на базі внутрішньої моделі (20), оберненої моделі $W_{O M}(s)=\frac{6,9523 s+1}{0,6222}$ та фільтра (13) із сталою часу $T_{\Phi}=\tau=4,3952$.

№ 4. Системи із зовнішнім регулятором (14), побудованим на базі внутрішньої моделі (22), оберненої моделі (23), фільтра $3 T_{\phi}=\tau=4,3952$ та внутрішнього контуру з ПД регулятором (21).

№ 5. Системи з ПІ регулятором із параметрами (16)

$$
W_{\text {III }}(s)=1,8400+\frac{0,2397}{s}
$$

та ПД регулятором (21).

Кожну з цих систем досліджували за допомогою середовища Matlab/Simulink для різних моделей об'єкта керування, поданих у табл. 1. Значення параметрів моделей $k=0,6222, T_{0}=3,5231$. Модель № 1 відповідає номінальному режиму роботи, у моделі № 2 коефіцієнт передачі $k$ збільшений у 2 рази, у моделі № 3 , окрім збільшення $k$ у 2 рази інерційність моделі збільшена на $30 \%$. Модель № 4 має параметри моделі № 3 і доповнена ланкою запізнення $3 \square=1$. Модель № 5 має коефіцієнт передачі, менший від номінального у 2 рази та інерційність, меншу на $30 \%$.

Табл. 1. Досліджувані моделі ОК

\begin{tabular}{|c|c|}
\hline № & Модель ОК \\
\hline 1 & $W_{\text {ОК }}(s)=\frac{k}{\left(T_{0} s+1\right)^{3}}$ \\
\hline 2 & $W_{\text {OК }}(s)=\frac{2 k}{\left(T_{0} s+1\right)^{3}}$ \\
\hline 3 & $W_{O K}(s)=\frac{2 k}{\left(T_{0} s+1\right)^{2}\left(2 T_{0} s+1\right)}$ \\
\hline 4 & $W_{O K}(s)=\frac{2 k e^{-\tau s}}{\left(T_{0} s+1\right)^{2}\left(2 T_{0} s+1\right)}$ \\
\hline 5 & $W_{O K}(s)=\frac{0,5 k}{\left(T_{0} s+1\right)^{2}}$ \\
\hline
\end{tabular}

У табл. 2-5 наведено значення прямих показників якості перехідних процесів, отриманих зміною заданого значення $x_{\text {зад }}(t)$ та збурення $d(t)$ на $1(t)$ для всіх п'яти систем керування. Під час моделювання визначали такі показники якості: $\sigma$ - максимальне динамічне перевищення заданого значення (у \% для процесів зміною $\left.x_{\text {зад}}(t)\right)$ і в абсолютних одиницях для процесів зміною $d(t)) ; t_{r}$ - час зростання до $95 \%$ усталеного процесу, $t_{\max }$ - піковий час, $t_{s}$ - час регулювання, за який вихідна величина $з$ похибкою $2 \%$ досягає заданого значення.

На графіках перехідних процесів позначено: 1 - система № 1 з ПІД регулятором; 2 - система № 2 з ПІ-ПД регуляторами; 3 - система № 3 із внутрішньою моделлю ОК (11) і допоміжним контуром із ПД регулятором; 
4 - система № 4 з моделлю регулятора (14) та допоміжним замкнутим контуром із ПД регулятором; 5 - систе-

ма № 5 з ПІ регулятором (26) та з ПД регулятором.

Табл. 2. Показники якості системи № 1 з ПІД регулятором (див. рис. 1)

\begin{tabular}{|c|c|c|c|c|c|c|c|}
\hline \multirow{2}{*}{ Модель ОК } & \multicolumn{9}{|c|}{$x_{\text {зад }}(t)=1(t)$} & \multicolumn{3}{c|}{$d(t)=1(t)$} \\
\cline { 2 - 9 } & $\sigma, \%$ & $t_{r}$ & $t_{\max }$ & $t_{s}$ & $\sigma$ & $t_{\max }$ & $t_{s}$ \\
\hline 1 & 13,00 & 13,167 & 20 & 31,415 & 0,283 & 12,366 & 27,833 \\
\hline 2 & 32,10 & 8,438 & 13,662 & 31,675 & 0,405 & 10,110 & 29,007 \\
\hline 3 & 45,91 & 12,660 & 17,301 & 67,960 & 0,393 & 12,652 & 51,967 \\
\hline 4 & 62,75 & 10,671 & 18,173 & 87,940 & 0,442 & 13,891 & 82,622 \\
\hline 5 & - & 24,384 & - & 49,003 & 0,170 & 10,705 & 43,809 \\
\hline
\end{tabular}

Табл. 3. Показники якості системи № 2 із ПІ-ПД регуляторами (див. рис. 3)

\begin{tabular}{|c|c|c|c|c|c|c|c|}
\hline \multirow{2}{*}{ Модель ОК } & \multicolumn{9}{|c|}{$x_{\text {зад }}(t)=1(t)$} & \multicolumn{3}{c|}{$d(t)=1(t)$} \\
\cline { 2 - 8 } & $\sigma, \%$ & $t_{r}$ & $t_{\max }$ & $t_{s}$ & $\sigma$ & $t_{\max }$ & $t_{s}$ \\
\hline 1 & 0,75 & 29,998 & 47,878 & 33,094 & 0,289 & 13,791 & 44,193 \\
\hline 2 & 4,27 & 17,430 & 28,020 & 39,174 & 0,395 & 11,124 & 33,375 \\
\hline 3 & 11,6 & 17,131 & 26,89 & 43,075 & 0.397 & 13,831 & 51,331 \\
\hline 4 & 15,24 & 16,555 & 25,567 & 41,821 & 0,434 & 14,659 & 51,853 \\
\hline 5 & - & 68,815 & - & 86,494 & 0,181 & 12,827 & 66,746 \\
\hline
\end{tabular}

Табл. 4. Показники якості системи № 3 із внутрішньою моделлю (11) ОК і замкнутим контуром з ПД регулятором

\begin{tabular}{|c|c|c|c|c|c|c|c|}
\hline \multirow{2}{*}{ Модель ОК } & \multicolumn{9}{|c|}{$x_{\text {зад }}(t)=1(t)$} & \multicolumn{3}{c|}{$d(t)=1(t)$} \\
\cline { 2 - 8 } & $\sigma, \%$ & $t_{r}$ & $t_{\max }$ & $t_{s}$ & $\sigma$ & $t_{\max }$ & $t_{s}$ \\
\hline 1 & - & 29,167 & - & 37,064 & 0,249 & 12,478 & 45,015 \\
\hline 2 & 0,42 & 17,541 & 33,818 & 21,022 & 0,325 & 9,855 & 36,674 \\
\hline 3 & 4,13 & 14,400 & 22,501 & 33,299 & 0,331 & 12,449 & 34,068 \\
\hline 4 & 7,73 & 13,114 & 18,830 & 30.833 & 0,371 & 13,242 & 32,290 \\
\hline 5 & - & 62,356 & - & 81,970 & 0,161 & 12,002 & 62,351 \\
\hline
\end{tabular}

Табл. 5. Показники якості системи № 4 із внутрішньою моделлю (22) та замкнутим контуром 3 ПД регулятором (див. рис. 4)

\begin{tabular}{|c|c|c|c|c|c|c|c|}
\hline \multirow{2}{*}{ Модель ОК } & \multicolumn{4}{|c|}{$x_{3 a d}(t)=1(t)$} & \multicolumn{3}{|c|}{$d(t)=1(t)$} \\
\hline & $\sigma, \%$ & $t_{r}$ & $t_{\max }$ & $t_{s}$ & $\sigma$ & $t_{\max }$ & $t_{s}$ \\
\hline 1 & - & 22,170 & - & 30,058 & 0,220 & 11,372 & 38,737 \\
\hline 2 & 0,04 & 11,644 & 36,567 & 18,139 & 0,281 & 8,906 & 33,332 \\
\hline 3 & 8,80 & 10,500 & 15,307 & 22,375 & 0,288 & 11,273 & 30,37 \\
\hline 4 & 19,13 & 9,991 & 14,583 & 28,659 & 0,332 & 12,178 & 24,705 \\
\hline 5 & - & 49,487 & - & 65,845 & 0,143 & 10,710 & 51,115 \\
\hline
\end{tabular}

Табл. 6. Показники якості системи № 5 з моделлю ПІ регулятора (26) та ПД регулятором (21)

\begin{tabular}{|c|c|c|c|c|c|c|c|}
\hline \multirow{2}{*}{ Модель ОК } & \multicolumn{9}{|c|}{$x_{\text {зад }}(t)=1(t)$} & \multicolumn{3}{c|}{$d(t)=1(t)$} \\
\cline { 2 - 8 } & $\sigma, \%$ & $t_{r}$ & $t_{\max }$ & $t_{s}$ & $\sigma$ & $t_{\max }$ & $t_{s}$ \\
\hline 1 & - & 16,516 & - & 20,034 & 0,240 & 11,659 & 35,861 \\
\hline 2 & 6,01 & 9,491 & 13,048 & 16,875 & 0,319 & 9,294 & 31,263 \\
\hline 3 & 18,93 & 10,810 & 16,250 & 33,078 & 0,320 & 11,680 & 24,464 \\
\hline 4 & 31,96 & 10,827 & 16,454 & 35,502 & 0,365 & 12,807 & 42,805 \\
\hline 5 & - & 47,380 & - & 62,875 & 0,151 & 10,716 & 49,463 \\
\hline
\end{tabular}

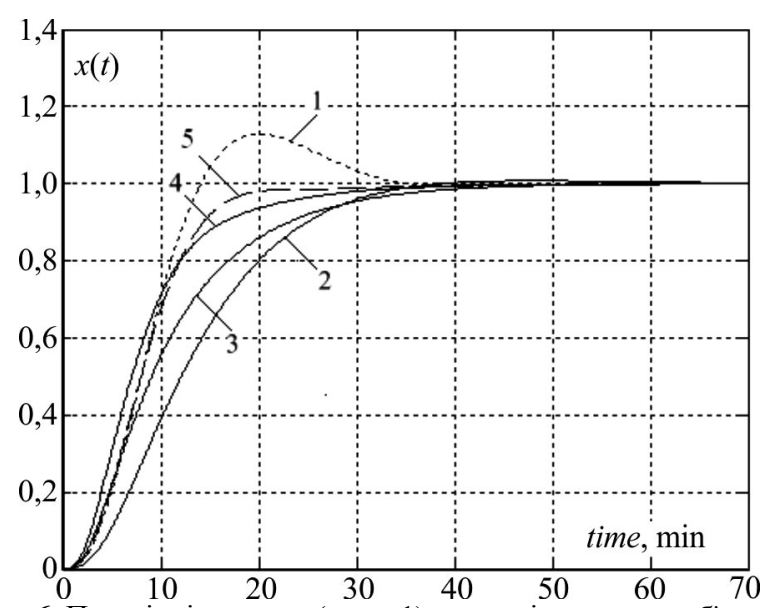

Рис. 6. Перехідні процеси $\left(x_{\text {зад }}=1\right)$ систем із моделлю об'єкта керування № 1

Порівняємо показники якості проектованої систем при зміні заданого значення. 3 табл. 2-6 та рис. 6 видно, що в номінальному режимі найбільш швидкодіючою $є$ система № 5, для якої за відсутності перегулювання час регулювання становить $t_{s}=20,034$. Задовільні показники мають також система № 4, для якої час регулювання становитиме $t_{s}=30,058$, і № 13 ПІД регулятором цей час вже становитиме $t_{s}=31,415$.

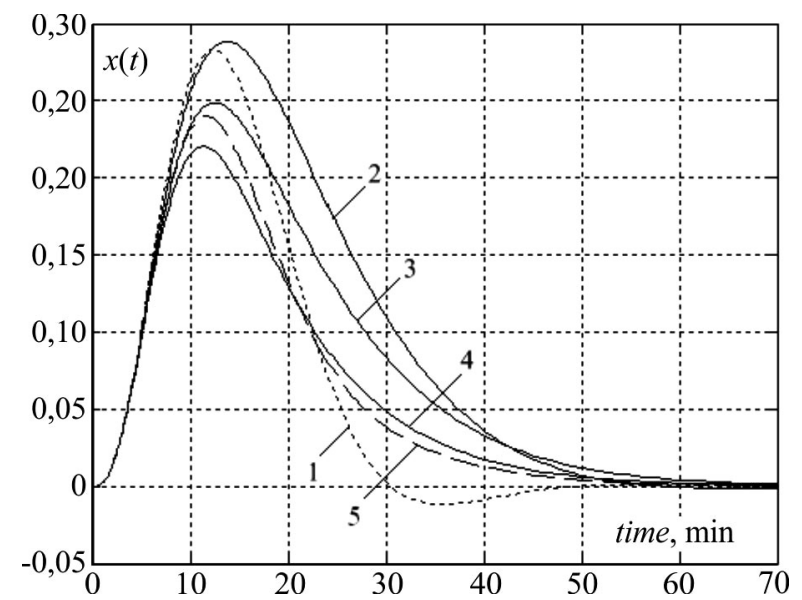

Рис. 7. Перехідні процеси $(d(t)=1)$ систем із моделлю об'єкта керування № 1 
На відміну від систем № 4, 5 одноконтурна система працює 3 динамічним перевищенням $\sigma=13 \%$. Зі збільшенням коефіцієнта передачі об'єкта керування у 2 рази (модель об'єкта керування № 2) у системах № 3, 4 виникає динамічне перевищення заданого значення менше $0,42 \%$, а у системах № 2, 5, $1 \sigma$ збільшується до 4,27, 6,01 і 32,10 \% відповідно. Найменший час регулювання спостерігається в системах № 4, 5. Зі збільшенням інерційності та появою запізнення (модель 4) максимальне динамічне перевищення $\sigma$ у всіх системах ще далі збільшується, а в системах з ПІД регулятором сягає недопустимого значення $62,75 \%$ (рис. 8). Найменший час регулювання $t_{s}=28,659$ спостерігається у системі № 4 .

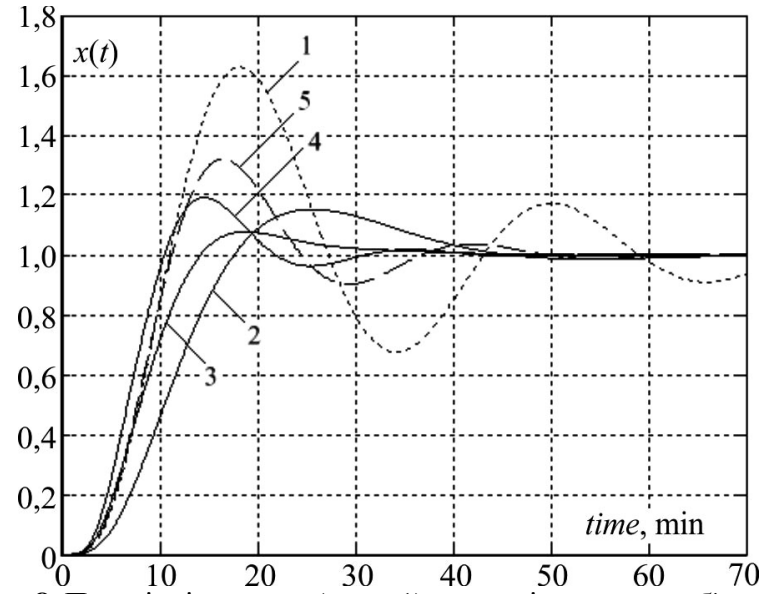

Рис. 8. Перехідні процеси $\left(x_{3 а д ~}=1\right)$ систем із моделлю об'єкта керування № 4

У перехідних процесах всіх систем керування з моделлю об'єкта № 5 (рис. 10) усувається динамічне перевищення заданого значення й істотно збільшується час регулювання. Найкоротший час регулювання спостерігався у системах № $1\left(t_{s}=49,003\right)$, а найдовший - у системах № $2\left(t_{s}=86,494\right)$ і № $3\left(t_{s}=81,970\right)$.

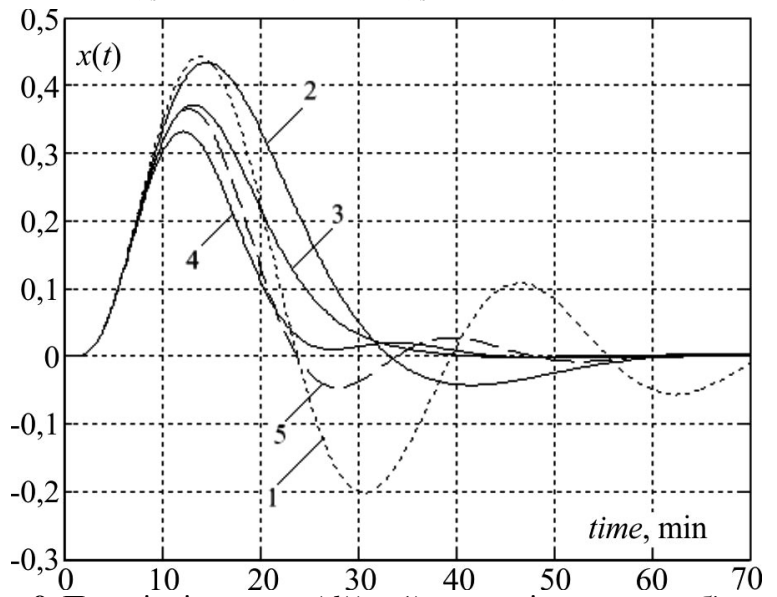

Рис. 9. Перехідні процеси $(d(t)=1)$ систем із моделлю об'єкта керування № 4

Порівнюючи перехідні процеси за збуренням (див. табл. 2-6 і рис. 7, 9, 11), можна відзначити, що для всіх досліджуваних моделей ОК, система керування № 4 забезпечує найменше максимальне динамічне перевищення регульованою величиною заданого значення. Для номінальних значень параметрів моделі № 1 найменший час регулювання $t_{s}=27,833$ забезпечує система 3 ПІД регулятором. Але зі зміною параметрів об'єкта керування, наприклад для моделі № 4 (див. рис. 9), час регулювання для цієї системи збільшується внаслідок виникнення значної коливальності. Разом $з$ тим, у системі
№ 4 час регулювання $є$ найменший і дорівнює 24,705. 3і зменшенням коефіцієнта передачі у 2 рази та зменшенням інерційності на $30 \%$ (модель об'єкта керування № 5) час регулювання для всіх систем збільшується на $30-60 \%$.

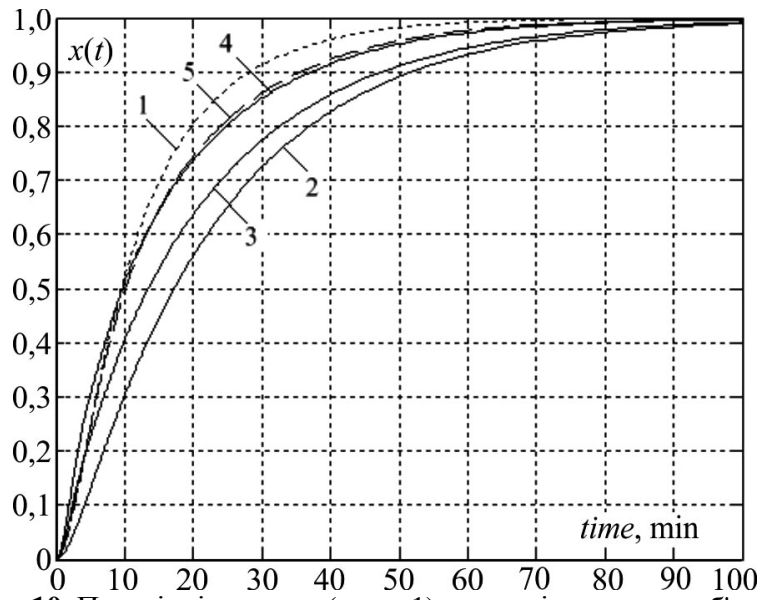

Рис. 10. Перехідні процеси $\left(x_{\text {зад }}=1\right)$ систем із моделлю об'єкта керування № 5

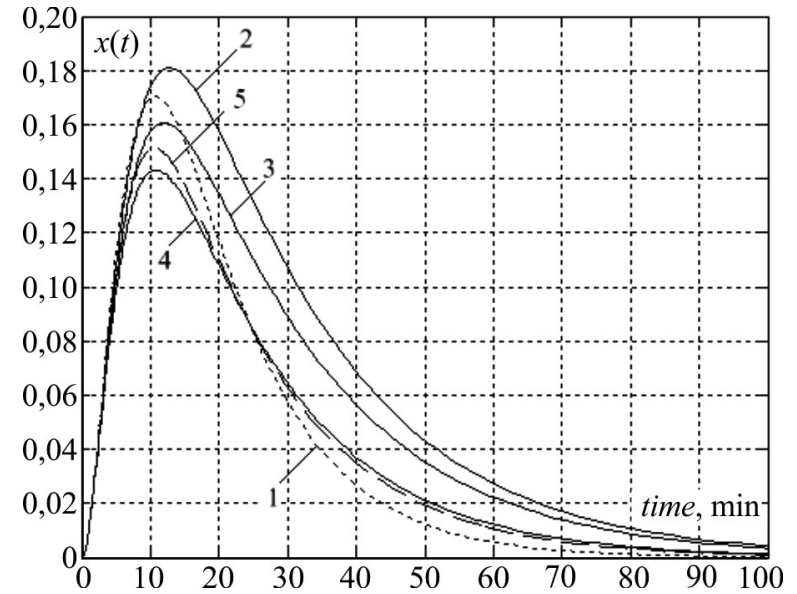

Рис. 11. Перехідні процеси $(d(t)=1)$ систем із моделлю об'єкта керування № 5

Обговорення отриманих результатів. Результати моделювання та порівняльного аналізу роботи систем керування з різними структурними схемами та регуляторами різної структури показали, що одноконтурна система керування з ПІД регулятором забезпечує необхідну якість регулювання в номінальному режимі роботи об'єкта. У разі зміни властивостей об'єкта керування, а саме збільшення коефіцієнта передачі та інерційності, перевагу мають багатоконтурні системи із зовнішнім контуром та додатковим внутрішнім контуром з ПД регулятором. Перехідні процеси в таких системах за каналами завдання та збурення мають менші динамічні відхилення. Серед цих систем кращими є системи, в яких зовнішній регулятор побудований на базі внутрішньої моделі об'єкта керування. Вони забезпечують стійке керування 3 достатнім запасом стійкості в умовах збільшення/зменшення коефіцієнта передачі у 2 рази, а також збільшення/зменшення інерційності щонайменше на 30 \%. Для таких змін параметрів моделі об'єкта керування перспективнішою є система № 4, в якій зовнішній контролер побудований на підставі внутрішньої моделі замкнутого контуру з ПД керуванням. Подібні властивості має також система № 5. Проведений аналіз показав, що система № 4 ефективно працює як при зміні заданого значення, так і за дії збурення. 
Висновки. На підставі імітаційного моделювання проаналізовано функціонування замкнутих систем керування з різними структурними схемами в умовах зміни властивостей інерційного об'єкта керування, а саме за збільшення/зменшення коефіцієнта передачі об'єкта керування у 2 рази та збільшення/зменшення інерційності на $30 \%$. Порівняли роботу таких систем: одноконтурної з ПІД регулятором, багатоконтурних з ПІ-ПД керуванням та систем із зовнішнім регулятором на підставі внутрішніх моделей об'єкта керування та внутрішнього замкнутого контуру з ПД регулятором.

Під час вирішення сформульованих завдань отримано такі нові наукові результати:

1. Доведено можливість побудови багатоконтурної системи, яка поєднує ПІ-ПД принцип керування і керування на підставі внутрішньої моделі та має теоретичні передумови для робастного керування.

2. Запропоновано структуру зовнішнього регулятора на базі внутрішньої моделі замкнутого внутрішнього контуру з ПД регулятором, що дає змогу покращити ефективність керування.

3. Отримано модель зовнішнього регулятора на підставі знайдених наближених моделей об'єкта керування та внутрішнього замкнутого контуру з ПД регулятором i iii наближену обернену модель. Знайдені моделі дають змогу реалізувати зовнішній регулятор.

4. Отримано параметри знайдених математичних моделей, які дають змогу налаштувати систему керування за спрощеною процедурою.

Практична цінність запропонованої системи керування полягає в отриманні задовільних показників якості при зміні параметрів регульованого об'єкта. Так, зокрема, за збільшення параметрів об'єкта керування система має найменший час регулювання при зміні заданого значення, а при зміні збурення - найменше динамічне відхилення для всіх досліджуваних моделей об'єкта керування.

Надалі необхідно вибрати критерій та методику налаштування регуляторів запропонованої системи і дослідити, при яких змінах властивостей об'єкта система керування забезпечить необхідні показники якості.

\section{References}

Astrom, K. J., \& Hagglund, T. (2005). Advanced PID Control. ISA The Instrumentation, Systems, and Automation Society, Research Triangle Park, $457 \mathrm{p}$.

Denysenko, V. (2009). Kompiuternoye upravleniye tekhnolohicheskim protsessom, eksperimentom, oborudovaniyem. Moscow: Horyachaya liniya - Telekom, 608 p. [In Russian].
Kovryho, Yu., Stepanets, O., Bahan, T., \& Bunke, O. (2017). Suchasna teoriia upravlinnia. (Part 2. Prykladni aspekty suchasnoi teorii upravlinnia). Kyiv: KPI im. Ihoria Sikorskoho, 155 p. [In Ukrainian].

Movchan, A., \& Stepanets, O. (2011). Adaptyvni ta parametrychnooptymalni systemy upravlinnia. Kyiv: NTUU "KPI", 108 p. [In Ukrainian].

Zhukov, S., \& Vazhynskyi, A. (2017). Adaptive control system of electrical equipment. (Ser. Energetics: reliability and energy efficiency). Bulletin of NTU "KhPI", 5(1235), 35-39. [In Ukrainian].

Karakawa, K., Abe, N., \& Ichihara, H. (2002). Joint design method of closed-loop identification and IMC structure for temperature control system with time delay. Proceedings of the 41st SICE Annual Conference, 3, 1592-1595.

Wang, R., Watanabe, K., Muramatsu, E., Ariga, Yu., \& Endo, Sh. (2006). Robust control via internal model principle. Proceedings of the 17th Internstional Symposium on Mathematical Theory of Networks and Systems, Kyoto, Japan, (pp. 2587-2589).

Remizova, O., \& Fokin, A. (2016). Robust control over sustainable technical object with time delay in control with disturbance compensation. Izv. vuzov. Priborostroenie, 59/12, 1010-1017. https://doi.org/10.17586/0021-3454-2016-59-12-1010-1017

Vilanova, R., Arrieta, O., \& Ponsa, P. (2018). Robust PI/PID controllers for load disturbance based on direct synthesis. ISA Transactions, 81, 177-196. https://doi.org/10.1016/j.isatra.2018.07.040

Kovryho, Yu., \& Bahan, T. (2015). Design of robust controller for objects with variable parameters. Doklady BHUIR, 2(88), 168-171. [In Russian].

Kovryho, Yu., Bahan, T., \& Ushchapovskyi, A. (2014). Designing control systems with controller based on internal model with two degrees of freedom. Eastern-European Journal of Enterprise Technologies, 4/11(70), 4-8. [In Ukrainian].

Stepanets, O. (2012). Control adaptive complex based on cascade system with object model. Eastern-European Journal of Enterprise Technologies, 2/10(56), 14-7. [In Russian].

Kovryho, Yu., Bahan, T., \& Bunke, O. (2013). Methods to ensure stability of control systems based on PI and PID controllers. EasternEuropean Journal of Enterprise Technologies, 3/3(63), 58-63. [In Ukrainian].

Kovryho, Yu., Bunke, O., \& Novikov, P. (2016). Dynamic correction application in control systems of inertial technological objects. Scientific Journal "ScienceRise", 1/2(18), 21-27. https://doi.org/10.15587/2313-8416.2016.58815

Onat, C. (2019). A new design method for PI-PD control of unstable processes with dead time. ISA Transactions, 84, 69-81.

Kaya, I. (2003). A PI-PD controller design for control of unstable and integrating processes. ISA Transactions, 42/1, 111-121.

Hassaan, A. G. (2014). Tuning of a PI-PD Controller used with a Highly Oscillating Second-Order Process. International Journal of Research and Innovative Technology, 1/3, 42-45.

Ali, H. I., \& Saeed, A. H. (2016). Robust PI-PD Controller Design for Systems with Parametric Uncertainties. Eng. \& Tech. Journal, 34, Part (A), 11, 2167-2173.

Dogruer, T., \& Tan, N. (2018). PI-PD Controllers Design Using Bode's Ideal Transfer Function. SSRN Electronic Journal, 1-6. https://doi.org/10.2139/ssrn.3271384

H. B. Krykh, H. F. Matiko, B. A. Kril

Lviv Polytechnic National University, Lviv, Ukraine

\section{SIMULATING THE SYSTEM BASED ON INTERNAL MODEL CONTROL}

Many technological processes have the task of effectively managing inertial plants which properties are changing. Lots of technical solutions are offered to manage such plants, including PI-PD control using predictive controllers and internal model controllers. Theoretically, systems with internal model provide high performance by changing the setpoint. However, the response to disturbance by dynamic deviation is not improved and may be quite prolonged. This article explores a multi-loop system that combines the properties of systems with PI-PD control and internal model control. We propose a system in which the structure of the external controller is realised on the basis of the internal model of the closed internal circuit with the PD controller. The mathematical model of the external controller is analyzed for the given inertial control plant. We recommend using an approximate model of the control plant in the form of first order plus dead time for the implementation of the external controller. An approximate inverted model was obtained on the basis of such a model. The obtained models enable simplifying the procedure of adjusting the external controller, since the controller parameters are analytically determined by the parameters of these models. The operation of the 
proposed system in the conditions of changing the properties of the inertial control plant was tested using simulation in Matlab/Simulink. The studying system was compared with other closed-loop control systems: single-loop with PID controller, multiloop with PI-PD control, systems with external controller based on the internal approximate models of the control plant and internal closed loop with PD controller, as well as the system with PI-PD control. The parameters of PI controller for the last system are found by a simplified model of an internal closed loop with the PD controller. The responses of systems to setpoint change and to disturbance change were analyzed. The control plant parameters were increased and decreased compared to the nominal values. Thus, when the transfer coefficient is increased by 2 times and the inertia is increased by $30 \%$ in the proposed system, the step responses by setpoint channel have the least settling time, and by the disturbance channel - the least dynamic deviation for all studied plant models. Therefore, the results show that the designed control system does not concede in robustness and in many studying conditions has better performance than the existing closed loop control systems.

Keywords: control plant; structural diagram; controller structure; step responses; performance of control system. 